\title{
Idiotype-Pulsed Autologous Dendritic Cell Vaccine APC8020
}

National Cancer Institute

\section{Source}

National Cancer Institute. Idiotype-Pulsed Autologous Dendritic Cell Vaccine APC8020.

NCl Thesaurus. Code C74042.

A cell-based cancer vaccine composed of autologous dendritic cells (DCs) pulsed with tumor-derived clonal immunog lobulin (Ig) with potential immunostimulatory and antineoplastic activities. Upon administration, idiotype-pulsed autologous dendritic cell vaccine APC8020, containing idiotype (Id) protein structures that can be recognized by antibodies and by CD41 T lymphocytes and CD81 T lymphocytes, may stimulate antitumoral cytotoxic T lymphocyte (CT L) and antibody responses ag ainst Id-expressing tumor cells. The Id represents the unique antigenic determinants in the variable regions of the clonal Ig. 